\title{
THE EFFECT OF JOB CHARACTERISTICS, EMPLOYEE EMPOWERMENT AND COMPENSATION ON PERFORMANCE ON CUSTOMER SERVICES OF BANK MANDIRI JEMBER BRANCH
}

\author{
Indah Susanti ${ }^{1}$ \\ Muhammad Firdaus ${ }^{2}$ \\ Yuniorita Indah Handayani ${ }^{3}$
}

\section{Higher Education of Economic Mandala}

Email: indahsusanti185@gmailcom

\begin{abstract}
This study aims to determine the effect of job characteristics, employee empowerment and compensation on employee performance at Bank Mandiri Jember Branch. The population in this study were all employees of PT. Bank Mandiri Tbk totaling 162 people. The sample in this study amounted to 41 respondents. The sampling technique used in this study is a non-probability sampling technique, namely the Accidental Sampling approach. The data analysis method used is multiple linear regression analysis. The results of this study indicate that the variables of job characteristics, employee empowerment and compensation have a simultaneous effect on employee performance at Bank Mandiri Jember Branch. Partially, these results also show that the variables of employee empowerment and compensation have a significant effect on employee performance. While the variable of job characteristics has no significant effect on the performance of employees of Bank Mandiri Jember Branch.
\end{abstract}

Keywords: Job Characteristics, Employee Empowerment, Compensation, Performance

\section{INTRODUCTION}

Along with the development of the era of globalization, every company is required to be responsive to economic changes that can occur at any time. Such conditions require companies to always be creative and innovate to face changes in management aspects, namely human resources, finance, marketing, and operations. The sustainability of an organization is strongly influenced by various aspects of management, one of which is the aspect of human resources (HR). The handling of human resources is different from other production factors because human resources are always growing and increasing both in quantity and quality. 
Human resources act as thinkers, planners and implementers of all activities in the organization. Therefore, organizations need human resource management that is able to manage all organizational resources so that they can function in accordance with what the organization expects.

Mas'ud 2002) states that employees are an important asset for the company (organization). Douglas (1996) explains that companies need employees who are able to work better and faster, so employees who have high job performance are needed. This shows the important role of HR in realizing a company that can last a long time in generating increasing and sustainable profits.

Performance means how well an employee is able to meet existing job requirements. According to Setiyawan and Waridin (2006) employee performance is the result or work performance of employees who are assessed in terms of quality and quantity based on work standards determined by the organization. Performance is often thought of as the achievement of tasks, where the term task itself comes from the thought of activities required by workers (Nelson, 2007).

High and low employee performance can be influenced by several factors, one of which is the characteristics of the job. According to Simamora (2006), the Job Characteristics Model theory states that an enriched job has a high level of difficulty, and which in turn creates a high level of critical psychological state in employees. This high critical psychological state will result in high work motivation, high performance, high job satisfaction and low absenteeism and turnover (Simamora, 2006). Job characteristics are an attempt to identify the task characteristics of a job, how these characteristics are combined to form different jobs and their relationship to employee empowerment, compensation and employee performance.

Another factor that can also affect performance is employee empowerment. Employee empowerment is an effort to encourage and enable individuals to take personal responsibility for their efforts to improve the way they carry out their jobs in the company, besides that employee empowerment can also increase the creativity, motivation and innovative power possessed by each employee in carrying out their duties. duties and responsibilities so that this can help realize the achievement of company goals. With the employee empowerment program, employee performance will increase. So that the company's goals will be achieved properly, quickly and flexibly. Therefore, often the way taken by the company to improve employee performance, motivation, commitment, and employee productivity is through employee empowerment. Clutterluck (2008: 54)

In addition, compensation also has an important role in improving employee performance. Compensation can improve work performance and employee motivation. Therefore, the company's attention to rational and fair compensation arrangements is needed. If employees perceive that compensation is inadequate for their work performance, their motivation and job satisfaction will tend to decrease. Samsudin, (2006: 187). Therefore, the compensation given to each employee must be proportional to the contribution that the employee has given to the company.

Bank Mandiri Jember Branch is one of the banks in Jember. One of the services provided is a service product for priority customers, namely customers who have savings of more than 1 billion at Bank Mandiri. This work unit requires good and excellent service, because customers who use this service are customers who do not 
only aim to save their money, but also want to get satisfaction and respect for the services provided by Bank Mandiri. Therefore, this work unit requires employees who have skills and knowledge that can be relied on in providing services to customers. Employee empowerment and employee selection according to the characteristics of a job are important for companies to get the right person in the right position. It aims to maximize the function of a work unit to match the objectives to be achieved. In addition, companies must also pay attention to the value of compensation given to employees with the given workload. It aims to motivate employees to improve their performance.

Performance is an important thing that must be achieved by every company anywhere, because performance is a reflection of the company's ability to manage and allocate its resources. Febryani (2003:42). Every company always strives to improve the performance of its employees, because with good employee performance the company's goals will be achieved well as expected, and vice versa if the employee's performance is bad then the company's goals will not be achieved properly.

Research on the effect of employee empowerment has been carried out by Kadirun (2013). The results of this study state that employee empowerment and compensation have a significant effect on employees at PT. Bank Rakyat Indonesia (Persero) Tbk. The results of other studies also state that employee motivation and empowerment significantly affect employee performance at PT. HD Motor 99 Denpasar Adetya (2016). In addition, Fadzilah (2006) also stated that Employee Empowerment and Self of Efficacy had a significant effect on the Performance of Sales Employees at PT Sinar Sosro.

Research on the effect of job characteristics on performance has been carried out by Aufan (2014). The results of this study state that the characteristics of the job which include skill variety, task significance, task identity, autonomy and feedback variables have a significant effect on the performance of employees of PT. Chevron Pacific Indonesia. Astuti (2015) also states that the diversity of skills and job characteristics has a significant effect on the performance of educators. In addition, Muhammad (2017) also stated that job characteristics and extrinsic motivation have a simultaneous and partial effect on employee performance at the Kendari City Licensing Office. The results of other studies also state that there is a positive influence between job characteristics and employee competencies on employee performance at CV. Fajar Mojokerto Fatimah Printing (2017).

Research on the effect of compensation on performance has been conducted by Nathania (2016). The results of this study indicate that the compensation variable has a positive and significant effect on employee performance at PD Damai Motor Bandar Lampung. Hidayah (2016) also states that the compensation variable has a positive effect on employee performance. In addition, Oktaviani (2015) also states that the Compensation Variable has an effect on Employee Performance at BMT Bina Insani Pringapus.

In previous studies, the factors used as independent variables were leadership style, motivation and compensation. As for some researchers used the variables of job characteristics and community empowerment as independent variables, but previous researchers only used one variable between job characteristics, employee empowerment and compensation. This study aims to determine the effect of job characteristics, employee empowerment and compensation on employee performance at Bank Mandiri Jember Branch. 


\section{RESEARCH METHOD}

This research is an Explanatory Research. According to Singarimbun and Effendi (1995:5) this type of research uses Explanatory Research, which is a research method to examine whether there is a pattern of relationships between two or more variables. In this study, researchers took a sample of 41 respondents or $25 \%$ of the total population $(25 \%$ X $162=40.5)$ rounded up to 41 respondents. The sampling technique used in this study is a non-probability sampling technique, namely the Accidental Sampling approach. Accidental Sampling is a technique of determining samples based on chance, that is, anyone who coincidentally meets a researcher can be used as a sample if it is deemed that the person who happened to be met is suitable as a data source (Sugiyono, 2012: 67).

The variables in this study consisted of three independent variables, namely job characteristics, employee empowerment and compensation and 1 dependent variable, namely employee performance. Job characteristics (X1) Job characteristics are the nature of the task which includes the amount of responsibility and the various tasks carried out by employees as measured by various skills, task identity, task significance and degree of autonomy. Employee Empowerment (X2) is a continuous interpersonal relationship to build trust between employees and management which is measured by indicators of desire, trust, confidence, credibility, accountability and communication. Compensation (X3) is all income in the form of money or goods directly or indirectly received by employees in return for services provided to the company as measured by indicators of salary, incentives, transportation allowance, health allowance and family allowance. Employee performance is a record of work results obtained from certain job functions or activities by employees of Bank Mandiri Jember branch for a certain period of time as measured by quality, quantity and timeliness.

The data analysis method used multiple linear regression analysis. Multiple regression analysis is used to predict how the condition of the dependent variable $(\mathrm{Y})$, if two or more independent variables $(\mathrm{X})$ as predictors are manipulated. So multiple regression analysis will be carried out if the number of independent variables is at least two (Sugiyono, 2012: 275). The test is done by using multiple linear regression analysis because it uses 4 independent variables which aims to determine the effect of the variables of job characteristics, employee empowerment, compensation on employee performance. Before performing multiple linear regression analysis, the validity and reliability of the data were first tested with the aim of knowing how valid the data obtained from the questionnaire distribution was and to find out the extent to which the measurement results remained consistent, if two or more measurements were made on the same symptoms as using the same measuring instrument. After that, the classical assumption test was carried out which included data normality test, multicollinearity test and heteroscedasticity test. To find out the relationship between the independent variable and the dependent variable, a hypothesis test was conducted using the t-test.

\section{RESULT ANALYSIS}

\section{Data Validity Test}

The validity test can also be done by comparing the r-count value with the r-table value. The basis for making decisions from the validity test:

a. If $r$ is positive and rcount $>$ rtable, then the variable is valid

b. If $r$ is positive and rcount $<$ rtable, then the variable is invalid 
The results of the analysis of the validity test using SPSS for Windows. can be seen in
Table below:

Table 1. Data Validity Test Results

\begin{tabular}{ccccccc}
\hline Variable & Indicator & r-count & r-table & $\begin{array}{c}\text { Recomendation } \\
\text { Value }\end{array}$ & Sig. & Information \\
\hline & $\mathrm{X}_{1.1}$ & 0,314 & 0,267 & 0,30 & 0,046 & Valid \\
Job Characteristics & $\mathrm{X}_{1.2}$ & 0,668 & 0,267 & 0,30 & 0,000 & Valid \\
$\left(\mathrm{X}_{1}\right)$ & $\mathrm{X}_{1.3}$ & 0,579 & 0,267 & 0,30 & 0,000 & Valid \\
& $\mathrm{X}_{1.4}$ & 0,569 & 0,267 & 0,30 & 0,000 & Valid \\
\hline & $\mathrm{X}_{2.1}$ & 0,322 & 0,267 & 0,30 & 0,040 & Valid \\
& $\mathrm{X}_{2.2}$ & 0,359 & 0,267 & 0,30 & 0,021 & Valid \\
Employee & $\mathrm{X}_{2.3}$ & 0,363 & 0,267 & 0,30 & 0,020 & Valid \\
Empowerment & $\mathrm{X}_{2.4}$ & 0,632 & 0,267 & 0,30 & 0,000 & Valid \\
$\left(\mathrm{X}_{2}\right)$ & $\mathrm{X}_{2.5}$ & 0,628 & 0,267 & 0,30 & 0,000 & Valid \\
& $\mathrm{X}_{2.6}$ & 0,629 & 0,267 & 0,30 & 0,000 & Valid \\
\hline & $\mathrm{X}_{3.1}$ & 0,570 & 0,267 & 0,30 & 0,000 & Valid \\
& $\mathrm{X}_{3.2}$ & 0,335 & 0,267 & 0,30 & 0,032 & Valid \\
Compensation & $\mathrm{X}_{3.3}$ & 0,626 & 0,267 & 0,30 & 0,000 & Valid \\
$\left(\mathrm{X}_{3}\right)$ & $\mathrm{X}_{3.4}$ & 0,643 & 0,267 & 0,30 & 0,000 & Valid \\
& $\mathrm{X}_{3.5}$ & 0,503 & 0,267 & 0,30 & 0,001 & Valid \\
\hline \multirow{2}{*}{ Performance } & $\mathrm{X}_{4.1}$ & 0,832 & 0,267 & 0,30 & 0,000 & Valid \\
$(\mathrm{Y})$ & $\mathrm{X}_{4.2}$ & 0,685 & 0,267 & 0,30 & 0,000 & Valid \\
& $\mathrm{X}_{4.3}$ & 0,691 & 0,267 & 0,30 & 0,000 & Valid \\
\hline
\end{tabular}

Source: Data Processed

Based on the calculation of the validity of the research data instrument, the results obtained that 18 indicators or question items from the Job Characteristics variable (X1), Employee Empowerment (X2), Compensation (X3) and the Performance variable (Y) are all valid because the total item correlation coefficient value ( $\mathrm{r}$-count) exceeds 0.30 with a significance level of $\mathrm{p}<$ 0.05 . The significance test of the validity of the instrument was also carried out by comparing the r-count value with the r-table for degree of freedom $(\mathrm{df})=\mathrm{N}-2$ in this pretest the number of samples (n) was 41 so that the magnitude (df) was 39 with a significance level of $5 \%$ then it is known that the r-table value is 0.260 . Based on the table above, it is proven that all indicators can be proven valid because all r-count values are greater than r-table.

\section{Reliability Test}

To test the reliability, it is done by looking for the reliability number of the questions from the questionnaire with the standard formula for alpha items. After obtaining the alpha value, then comparing this value with the critical number that has been determined. In this test, the reliability test uses SPSS software for windows with the Cronbach Alpha statistical approach. Because the number of questions for each variable is less than ten items, then a variable is said to be reliable if the Cronbach Alpha value is > 0.60 (Santoso, 2002:200). 
The results of the data reliability test can be seen in Table below:

Table 2. Research Data Instrument Reliability

\begin{tabular}{cccc}
\hline Variable & $\begin{array}{c}\text { Cronbach's } \\
\text { Alpha }\end{array}$ & Rekomendation & Information \\
\hline Job Characteristics & 0,677 & 0,60 & Reliable \\
Employee & 0,664 & 0,60 & Reliable \\
Empowerment & 0,690 & 0,60 & Reliable \\
Compensation & 0,795 & 0,60 & Reliable \\
Performance & & &
\end{tabular}

Source: Data Processed

This table shows that the value of for each variable is $>$ from the critical value of reliability. Job Characteristics Variable (X1) 0, 677> 0.60, Employee Empowerment variable $(\mathrm{X} 2) 0,664>0.60$, Compensation (X3) 0, 690>0.60, and Performance variable (Y) $0,795>0.60$. Thus it can be concluded that all question items in the questionnaire can be trusted because the measurement results are relatively consistent even though the question is given twice or more to different respondents so that this questionnaire can be used for further research. This means that all indicators used as a variable measuring instrument in this study can be trusted because each has a Cronbach's alpha value of more than 0.60.

\section{Data Normality Test}

To find out the shape of the data distribution can use the P-Plot graph. In the P-Plot graph, data will be normally distributed and can be detected by looking at the spread of data (points) on the diagonal axis of the graph. The results of the data normality test can be seen in Figure below:

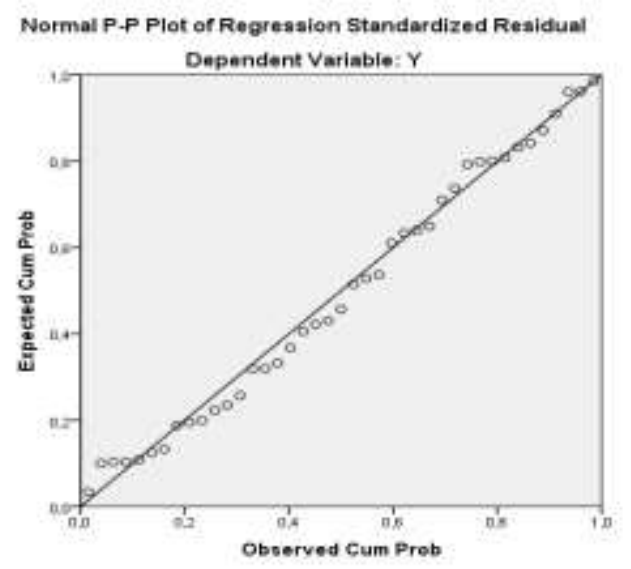

Figure 1. Normality Test

Based on the results of normality testing of data through SPSS 21.0 software, it can be seen that the data spreads around the diagonal line and follows the direction of the diagonal line, so that the regression model meets the assumption of normality.

\section{Multicollinearity Test}

Multicollinearity test was conducted to test whether the regression model found a correlation between the independent variables or not. A good regression model is if there is no correlation between variables. 
The method for testing the presence or absence of multicollinearity can be seen from the Tolerance and Variance Inflation Factor (VIF) values with the cut off value commonly used to indicate the presence of multicollinearity is the Tolerance value 0.1 or the same as the VIF value 10 (Gujarati, 1991: 299).

The results of the Multicollinearity Test can be seen in Table below:

Table 3. Multicollinearity Test

\begin{tabular}{cccc}
\hline Variable & VIF & Tolerance & Infromation \\
\hline $\mathrm{X}_{1}$ & 1,092 & 0,916 & There is no \\
$\mathrm{X}_{2}$ & 1,098 & 0,911 & Multicollinearity \\
$\mathrm{X}_{3}$ & 1,175 & 0,851 & \\
\multicolumn{2}{l}{ Source: Data Processed } & &
\end{tabular}

The results of Table show that the regression model has a VIF value of each variable less than 10 and a tolerance value of more than 0.1 . So it can be concluded that the regression model in this study does not occur multicollinearity symptoms.

\section{Heteroscedasticity Test}

This assumption states that whether in the regression model there is an inequality of variance from one residual to another observation. If the variance of one residual of one other observation remains, it is called homoscedasticity. The test results can be seen in Figure below:

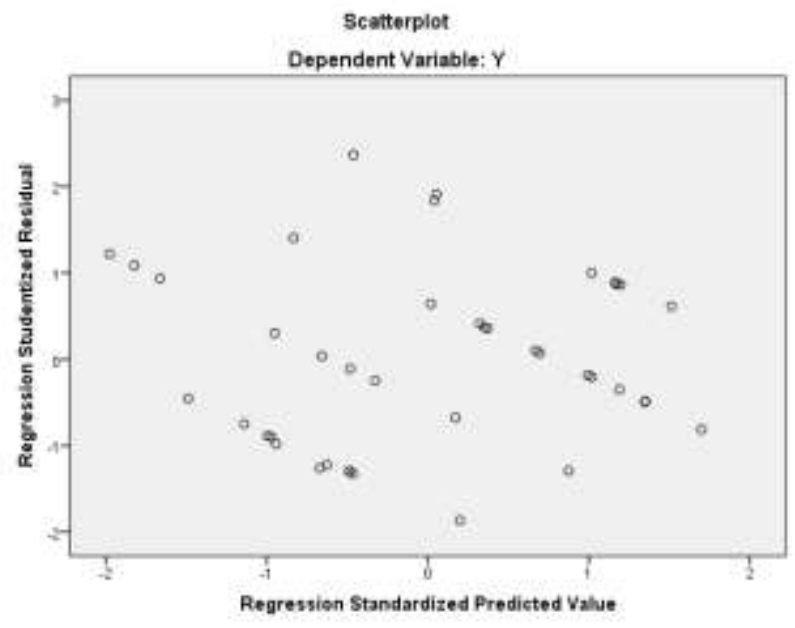

Figure 2. Normality Test

Based on the picture of the results of the Heteroscedasticity Test, it can be seen that the test results describe no clear pattern, the points spread above and below the number 0 on the $\mathrm{Y}$ axis. So it can be concluded that in the regression model there are no symptoms of heteroscedasticity.

\section{Multiple Linear Regression Analysis}

In analyzing the data in this study, the method used by researchers to find out is multiple linear regression analysis. This analysis aims to determine the effect of variable job characteristics, employee empowerment, and compensation on employee performance at Bank Mandiri 
Jember Branch simultaneously and to determine the effect of variable job characteristics, employee empowerment, and compensation on employee performance at Bank Mandiri Jember Branch partially. The process of calculating multiple linear regression analysis in this study uses SPSS software version 21.0. The coefficient value indicated by the SPSS output value called the Coefficient is expressed as the Standardized Coeffitient or known as the Beta value. The results of multiple linear regression analysis can be seen in the following table:

Table 3. Multiple Linear Regression Analysis

\begin{tabular}{|c|c|c|c|c|c|c|c|c|}
\hline \multirow[t]{2}{*}{ Model } & & \multicolumn{2}{|c|}{$\begin{array}{c}\text { Unstandardized } \\
\text { Coefficients }\end{array}$} & \multirow{2}{*}{$\begin{array}{c}\text { Standardized } \\
\text { Coefficients } \\
\text { Beta }\end{array}$} & \multirow[t]{2}{*}{$t$} & \multirow[t]{2}{*}{ Sig. } & \multicolumn{2}{|c|}{ Collinearity Statistics } \\
\hline & & $B$ & Std. Error & & & & Tolerance & VIF \\
\hline \multirow{4}{*}{1} & (Constant) & 5,850 & 1,958 & & 2,988 &, 005 & & \\
\hline & $\mathrm{X} 1$ &, 006 & ,090 & ,009 &, 068 & ,946 & ,916 & 1,092 \\
\hline & $\mathrm{x} 2$ & , 122 &, 048 & ,332 & 2,545 &, 015 & ,911 & 1,098 \\
\hline & $\mathrm{X} 3$ & ,235 &, 066 & ,478 & 3,545 & ,001 &, 851 & 1,175 \\
\hline
\end{tabular}

a. Dependent Variable: $Y$

From the results of the regression output using the SPSS 21.0 program which can be seen in Table 4 above, a picture can be formed showing the relationship between the influence of each independent variable on the dependent variable as follows:

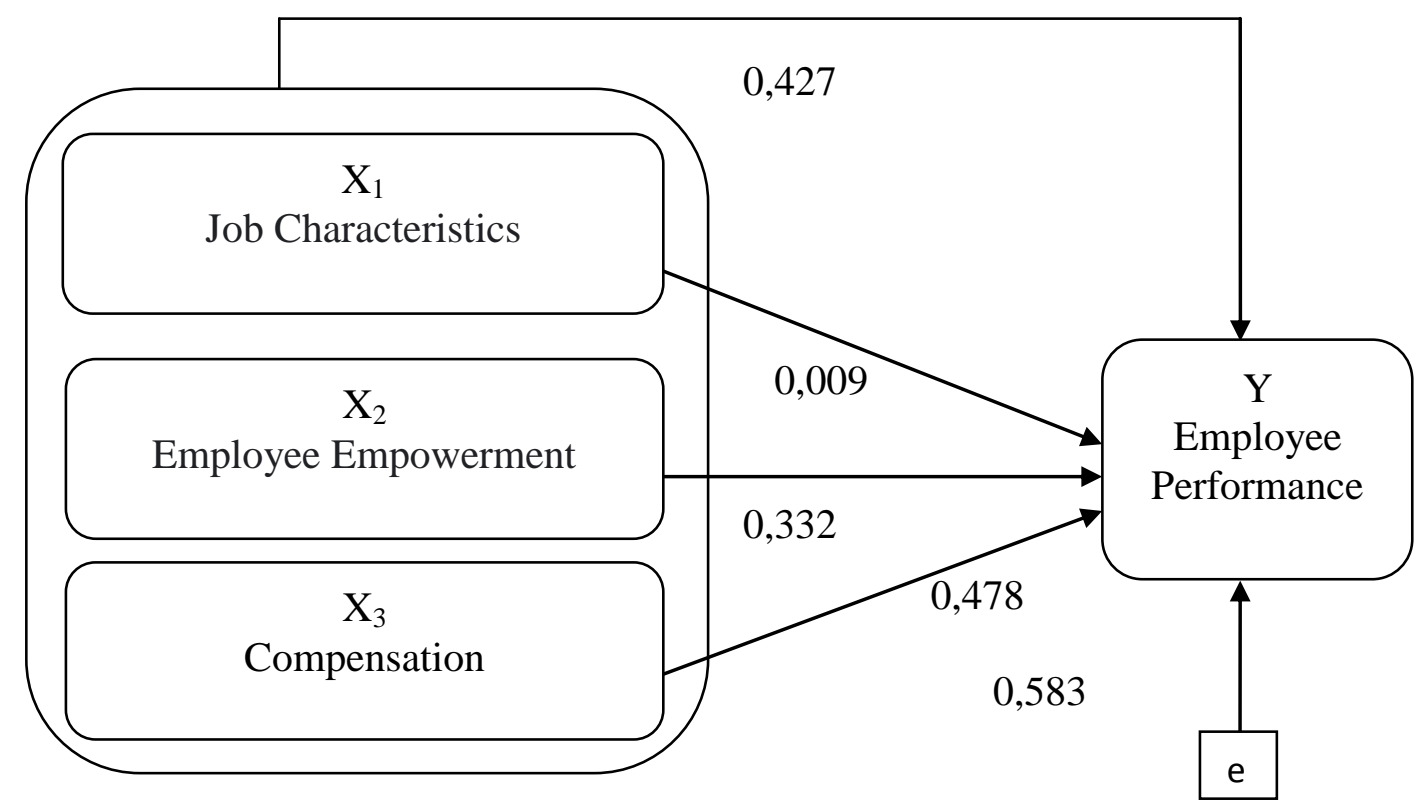

Figure 3. Research Conceptual Framework 
Based on the picture above, multiple linear regression equations can be formed as follows.

$$
Y=5,850+0,006 X_{1}+0,332 X_{2}+0,478 X_{3}
$$

\section{Hypothesis Test}

The first hypothesis states that there is a partial effect of Job Characteristics on Employee Performance at Bank Mandiri Jember Branch. Based on the results of multiple linear regression testing in Table 4, the t-count value for the job characteristics variable is 0.068 while the $t$-table is 1.684 (df 95 with a 5\% confidence level). This value indicates that the $t$-count value is smaller than the $\mathrm{t}$-table. While the significance value is 0.946 which is greater than 0.05. This means that the job characteristics variable has no effect on the performance of Bank Mandiri Branch employees.

The second hypothesis states that there is a partial effect of Employee Empowerment on Employee Performance at Bank Mandiri Jember Branch. Based on the results of multiple linear regression testing in Table 4, the t-count value for the employee empowerment variable is 2.545 while the t-table is 1.684 ( $\mathrm{df} 95$ with a $5 \%$ confidence level). This value indicates that the value of t-count is greater than t-table. While the significance value is 0.015 which is smaller than 0.05 . This means that the employee empowerment variable has a significant effect on the performance of Bank Mandiri Branch employees.

The third hypothesis states that there is a partial effect of compensation variables on employee performance at Bank Mandiri Jember Branch. Based on the results of multiple linear regression testing in Table 4, the t-count value for the compensation variable is 3.545 while the t-table is 1.684 (df 95 with a 5\% confidence level). This value indicates that the value of $t$-count is greater than $\mathrm{t}$-table. While the significance value is 0.001 which is smaller than 0.05 . This means that the compensation variable has a significant effect on the performance of Bank Mandiri Branch employees. In another sense, the higher the level of compensation provided by Bank Mandiri.

\section{INTERPRETATION}

Based on the previous hypothesis testing, it was stated that the job characteristics variable had no significant effect on the performance of Bank Mandiri Branch employees. This means that the level of suitability of the job characteristics of employees cannot improve employee performance at Bank Mandiri Jember Branch. This result rejects the findings of research conducted by Aufan (2014) which states that job characteristics have a significant effect on employee performance at PT. Chevron Pacific Indonesia. This study also rejects the findings of research conducted by Astuti (2015) which states that the suitability of job characteristics has a direct effect on performance. This study also rejects the findings of research conducted by Muhammad (2017) which states that job characteristics affect employee performance at the Kendari City Licensing Office.

The variable of job characteristics in this study is described in four indicators, namely; variety of skills, task identity, task significance and degree of autonomy. Based on the results of the study, it was stated that job characteristics had no effect on employee performance. This means that the type of work available at Bank Mandiri Jember Branch is not a job that requires special skills for human resources who carry out the work. Banking employees have various educational backgrounds ranging from economics, law, agriculture to literature. This proves that the characteristics of the work at Bank Mandiri can be carried out by human resources with a variety of basic education. In addition, employees at 
Bank Mandiri also have the freedom to be responsible for completing their work. This means that the degree of autonomy built within the Bank Mandiri Jember Branch is quite good, so that employees can help each other to complete any existing work. This is what causes that job characteristics have no effect on increasing employee performance.

Based on the results of hypothesis testing, it is stated that the employee empowerment variable has a significant effect on the performance of Bank Mandiri Branch employees. This means that the higher the level of employee empowerment carried out by Bank Mandiri, it will further improve employee performance at the Jember Branch of Bank Mandiri. These results support research conducted by Kadirun (2013) which states that Employee Empowerment has a significant effect on employee performance at PT. Bank Rakyat Indonesia (Persero) Tbk. This study also supports the findings of research conducted by Adetya (2016) which states that employee empowerment has a significant positive effect on the performance of PT. HD Motor 99 Denpasar. The same thing was conveyed in the findings of Fadzilah's (2006) study which stated that employee empowerment had a positive effect on the performance of employees in the Sales department at PT Sinar Sosro.

Employee empowerment variables in this study are described in six indicators, namely; Desire, Trust, Confident, Credibility, Accountability and Communication. The descriptive results of employee empowerment based on respondents' perceptions are in the high category. This shows that respondents feel that employee empowerment at Bank Mandiri is good. This is indicated by the delegation and involvement of employees in every important job in the company; creating conditions of mutual trust between managers and employees; The company always respects the abilities possessed by employees; The company always maintains credibility with awards and develops a work environment that encourages healthy competition; the employee is always responsible for the given authority; and Every employee has the freedom to communicate with superiors and coworkers. These factors can certainly provide high motivation for employees to improve their performance

Based on research conducted by Cacciope (1998) at Burswood Resort Hotel Australia, states that empowered employees can solve organizational and customer problems quickly, immediately, directly and professionally. For this reason, Bank Mandiri should continue to maintain employee empowerment efforts within the company, because employee empowerment can provide more opportunities for employees to develop creativity, flexibility and autonomy in their own work. This is believed to have a beneficial effect on employee recognition (self-estem). Employees will feel better and think positively about themselves and will be better prepared to serve customers. So that in the long term empowerment that is carried out continuously will be able to improve the performance of the company's employees themselves.

Based on the results of hypothesis testing, it is stated that the compensation variable has a significant effect on the performance of Bank Mandiri Branch employees. This means that the higher the level of compensation provided by Bank Mandiri, the higher the performance of employees at Bank Mandiri Jember Branch. These results support research conducted by Kadirun (2013) which states that compensation has a significant effect on employee performance at PT. Bank Rakyat Indonesia (Persero) Tbk. This study also supports the findings of research conducted 
by Hidayah (2016) which states that compensation has a positive effect on employee performance. The same thing was conveyed in Nathania's research findings (2016) which stated that compensation had a positive effect on employee performance at PD Damai Motor Bandar Lampung. In addition, Oktaviani (2015) also states that compensation has an effect on employee performance at BMT Bina Insani Pringapus.

The compensation variable in this study is described in five indicators, namely salary, incentives, transportation allowance, health allowance and family allowance. Descriptive results of compensation variables based on respondents' perceptions are in the high category. This shows that respondents feel that the compensation provided by Bank Mandiri to employees is quite good as indicated by the provision of salaries that are in accordance with the workload given; The company always provides additional incentives for overtime work; The transportation allowance provided is in line with employee expectations; The health benefits provided are in accordance with the risks of the job; and Family allowances provided are in line with employee expectations. The above factors can certainly encourage employees to improve their performance, because all forms of achievement as a result of employee performance always receive appropriate rewards from Bank Mandiri.

Siagan (2000) states that a good reward system is a system that is able to ensure the satisfaction of members of the organization which in turn allows the organization to acquire, maintain and employ a number of people who with various positive attitudes and behaviors work productively for the benefit of the organization. This clearly clarifies the important role that the provision of appropriate compensation to employees can increase employee work productivity which in turn makes it easier to achieve company goals. According to Mondy \& Noe (2005), the determinants of compensation originating from within the organization itself are compensation policies, organizational levels, organizational politics, and the ability to pay from the organization itself. For this reason, Bank Mandiri Jember Branch should continue to maintain a compensation system for employees, so that they are motivated to improve their performance.

\section{CONCLUSION}

Based on the results of research and discussion in the previous chapter, it can be concluded that the variables of employee empowerment and compensation have a significant effect on the performance of Bank Mandiri Branch employees. While the variable of job characteristics has no significant effect on the performance of Bank Mandiri Branch employees. This implies that in order to continue to improve employee performance, an important factor that must be considered by the company is the provision of compensation in accordance with the employee's workload. In addition, employee empowerment is also an important factor to support employee performance, because employee empowerment can provide more opportunities for employees to develop creativity, flexibility and autonomy in their own work. Job characteristics factors have no significant effect on employee performance. This shows that the division of tasks and delegation of authority within the Bank Mandiri Jember Branch has not run optimally. For this reason, it is recommended that Bank Mandiri conduct a review of the job descriptions in its environment.

\section{REFERENCES}

Adetya, 2016, Pengaruh Motivasi dan Pemberdayaan Karyawan Terhadap Kinerja Karyawan PT HD Motor 99 
Denpasar, Jurnal Manajemen, Vol 5, No 11, ISSN : 2302-8912, Fakultas Ekonomi dan Bisnis Universitas Udayana, Bali

Aufan, 2014, Analisis Pengaruh FaktorFaktor Karakteristik Pekerjaan Terhadap Kinerja Karyawan (Studi pada Karyawan PT Chevron Pacific Indonesia Departemen PG \& $T$ Minas), Jurnal, Fakultas Ekonomi Universitas Diponegoro, Semarang

Gujarati, Damodar, 2003, Ekonometri Dasar. Terjemahan: Sumarno Zain, Jakarta: Erlangga.

Hidayah, 2016, Pengaruh kompensasi terhadap kinerja karyawan melalui kepuasan kerja sebagai variabel intervening (Studi pada karyawan bagian keuangan dan akuntansi UNY), Jurnal Akuntansi, FAKULTAS Ekonomi, Universitas Negeri Yogyakarta

Kadirun, 2013, Pengaruh Pemberdayaan Karyawan dan Kompensasi terhadap Kinerja Karyawan Pada PT BRI TBK, Cabang Dago Bandung, Jurnal, Universitas Komputer Indonesia, Bandung

Sugiyono. 2012. Statistika untuk Penelitian. Bandung : Alfabeta 